\author{
Arkadiusz Bieliński \\ University of Bialystok \\ arbi@uwb.edu.pl
}

\title{
The Right to Have a Matter Adjudicated by a Court and Alternative Dispute Resolution - Selected Issues
}

\begin{abstract}
This article presents selected issues relating to the concept and realization of the right to court, comparing them with alternative methods of dispute resolution - ADR. It points out some of the causes leading to the crisis of traditional justice, and at the same time points out the advantages of alternative methods of complementary judicial procedures in those areas where they have weaknesses. There is now no doubt that the phenomenon of ADR in the current world cannot be ignored or downplayed. Slowly it begins to gain more and more importance, responding to the expectations of at least a part of the society in which the opinion of justice performed by the courts, is not able to fully satisfy their interests. Also, judges themselves are increasingly using methods of ADR, particularly mediation, seeing the case and its underlying factors, more suitably resolved by the parties themselves than by a decision made by the court. This could be due to various reasons: the complexity of the dispute, the dominant role of personal conflicts between the conflicting parties and therewith to the creation of communication barriers, more so than a straightforward legal issue. In these situations, because the court is rather powerless and doubtful despite the possibility of a binding decision by the judge, such judgement will probably be far from what the parties expected or consider to be "fair".
\end{abstract}

Keywords: the right to a court, ADR, justice, humanization, right to have a matter adjudicated by a court

\section{Introduction}

Alternative dispute resolution (ADR) in recent years has become a more and more noticeable phenomenon in Poland, even though the legal solutions that permit their functioning (in particular mediation) have been present in the Polish legal system for many years. Everything suggests therefore that something has changed in the perception of these "alternative" procedures. But alternative to what? It seems that especially in relation to the court of justice it seems that in the perception of citizens the court as the only competent body to make a definitive settlement of a dispute, which is effect of the conflict between the parties. The mere introduction of media- 
tion in the initial period of the "fascination of the court" has not changed, and citizens often treated it more as a procedural curiosity rather than an institution they actually want to use. As increased interest in methods of ADR can be observed, it appears advisable to allocate those in the justice system, in particular through the prism of being very recognizable by citizens of their right to court.

The starting point should be to make understanding of the right to have a matter adjudicated by a court, especially in terms of constitutional law. Then, it appears advisable to outline the causes of the crisis of traditional justice exercised by the courts, resulting in increased interest in ADR. Undoubtedly, it must at the same time raise issues related to the so-called humanization of the judicial process and the phenomenon of procedural fairness. In its conclusion, the paper indicates the place of alternative dispute resolution in the justice system - whether ADR functions somewhat beside the regular justice system or whether it provides a complementary service devoid of the weaknesses found in the competence and work of the judiciary.

\section{The right to have a matter adjudicated by a court in general}

The right to have a matter adjudicated by a court is a complex issue, both from a constitutional standpoint and that of individual branches of law. In brief, it can be said that the right to have a matter adjudicated by a court is an entitlement to anyone who falls under the jurisdiction of the Polish state. ${ }^{1}$ In addition to the Polish constitution, a number of provisions of international law fulfill the right to have a matter adjudicated by a court, which includes especially the European Convention on $\mathrm{Hu}$ man Rights and Fundamental Freedoms. ${ }^{2}$ Hoever, the understanding and realization of the right to have a matter adjudicated by a court is recorded inconsistently, depending on the type of matters that are subject to examination. Such an approach forces into being categories of cases that are subject to the regulation of individual branches of law, adjustment methods and court rules. In civil law, the right to have a matter heard in court is the right to bring an action that accrues to the plaintiff and the counterbalance the right to defense, which is the right of the respondent. ${ }^{3}$ It should be emphasized that the European Court of Human Rights in its decisions relating to art. 6 paragraph $1^{4}$ of the Convention, indicates that it provides anyone the inalienable right to court to settle all claims relating to the rights and obligations of a civil na-

1 Art. 45 Constitution of the Republic of Poland, Journal of Laws 1997, No. 78, item. 483, as amended.

2 Journal of Laws 1993, No. 61, item. 284, as amended.

3 J. Jasińska, Prawo do sądu na tle polskiego prawa cywilnego materialnego i procesowego, (in:) R. Sztychmiler, J. Krzywkowska, Problemy z sądową ochroną praw człowieka, tom I, Olsztyn 2012, p. 284. It defines the right to a fair trial. 
ture. It should be remembered, however, that the right to have a matter adjudicated by a court does not mean the right to a favourable verdict, but the fact that the request included in a claim should be recognized by the court and decided upon on its merits with approval or dismissal. ${ }^{5}$ The right to have a matter adjudicated by a court is also sometimes referred to in other terms, such as the right to justice, right to the courts, the right to a fair trial. Although these terms vary, in essence they mean the same thing. ${ }^{6}$ It is assumed that the party wishing to apply to the court for legal protection de facto uses three groups of rights: the right to ask the court to provide judicial protection (right to justice); the right to substantive examination of the request, depending on the existence of constitutional and procedural rules (formal right to action); the right to substantive consideration to request, dependant on the existence of substantive grounds (substantive right of action). ${ }^{7}$ Similarly, the Polish constitutional court defines the right to have a matter adjudicated by a court to consist of the following rights: the right of access to a court, which means the right to initiate a procedure before the court impartial and an independent; the right to appropriate judicial procedure in accordance with the requirements of fairness and transparency; the right to obtain a binding decision of the case by the court. ${ }^{8}$ The right to have a matter adjudicated by a court, because of its position in the constitution of freedom and personal rights is autonomous it is not only the instrument for carrying out other constitutional rights and freedoms but is an independent legal guarantee and is subject to protection regardless of the violation of other rights. ${ }^{9}$

\section{The causes of the crisis of traditional justice and alternative methods of dispute resolution}

Given regard to the foregoing, the question that appears is why, if the right to court is of such wide and autonomous character, the traditional justice exercised by the courts has for so many years been experiencing a crisis resulting in, among others, at-

5 J. Szczechowicz, Ochrona praw człowieka w aspekcie prawa dostępu do sądu w postępowaniu cywilnym, (in:) R. Sztychmiler, J. Krzywkowska, Problemy z sądową ochroną..., op. cit., p. 274.

6 See H. Mądrzak, Prawo do sądu jako gwarancja ochrony praw człowieka (studium na tle polskiego prawa konstytucyjnego, prawa cywilnego materialnego i procesowego), (in:) L. Wiśniewski (ed.), Podstawowe prawa jednostki i ich sądowa ochrona, Warszawa 1997, p. 187.

7 See Z. Resich, Przesłanki procesowe, Warszawa 1966, pp. 28-29; the same, Istota procesu cywilnego, Warszawa 1985, p. 25; P. Pogonowski, Realizacja prawa do sądu w postępowaniu cywilnym, Warszawa 2005, p. 7.

8 The decision of Constitutional Tribunal of 9 June 1998, K 28/97, OTK 1998, No. 4, item. 50.

9 See the decision of Constitutional Tribunal of 10 July 2000, SK 12/99, OTK 2000, No. 5, item. 143. The understanding of the constitutional right to court see A. Bieliński, Prawo do sądu a alternatywne metody rozwiązywania sporów ze szczególnym uwzględnieniem mediacji, (in:) Ł. Błaszczak (ed.), Konstytucjonalizacja postępowania cywilnego, Wrocław 2015, pp. 397-398 and the literature given there. 
tention being drawn to alternative methods of dispute resolution? The causes of this crisis are many and have different etiology. I will focus on those that in my opinion are critical.

First, the nature and structure of conflicts and disputes has changed. As Lech Morawski observes, alongside the traditional bipolar conflict of two parties, there are an increasing number of multipolar conflicts, with many parties with diverse interests that cannot be reduced to a common model. Traditional trials, due to their complexity and formalization, are not able to help solve such a highly complex configuration of interests. It is said that, the more complex the nature of the conflict, the simpler the resolution process should be in providing greater freedom to communicate in order to resolve it. Formal lawsuits do not fulfill this condition easily. With their highly formalized and hierarchical structure and focus on adherence to rules rather than the interests of the parties, courts take all the characteristics of bureaucratic organizations no longer able to meet the need for a rapid and flexible response to constantly changing situations and problems. ${ }^{10}$

Secondly, parties turn to the court as an impartial and independent body for legal protection, "justice" and "help". But as "just" will be recognized a reason of national judgment which may not or does not justify the result, at best it can be described as beyond comprehension and at worst it contains no convincing argument that the right of the opponent was more justified? Justice is defined by national interpretation, which to the parties involved can be incomprehensible and not linked to each other's expectation of what justice is about. The reasoning behind a judgment often come down to the fact that it is in compliance with applicable law and, more specifically, with its interpretation (the court convinces the only legitimate interpretation, and does not convince the parties on the merits of the case, or lack of them). A court's ruling on the proper interpretation of the law may do little to convince at least one party that the ruling constitutes "justice". Can it be encouraging for that party to be confronted with a bureaucratic machine which, as a remedy for his problem, conducts archaic legal proceedings that are not in any shape or form adapted to meet the challenges of changing realities? ${ }^{11}$ Probably in recognition of this fact the focus of attention has now shifted toward the humanization of civil trial proceedings. ${ }^{12}$ The process is intended to appropriately satisfy the needs of safety and due legal protection both in individual cases and group size cases. A civil court should be seen as a provider of services to the public, provisioning effective legal protection, maintaining confidence

10 L. Morawski, Proces sądowy, a instytucje alternatywne (na przykładzie sporów cywilnych), „Państwo i Prawo" 1993, No. 1, pp. 17-18.

11 A. Bieliński, Prawnik i jego misja w ramach procedur alternatywnego rozwiązywania sporów w warunkach kryzysu klasycznego wymiaru sprawiedliwości, „Kwartalnik ADR” 2013, No. 2, p. 30 .

De-humanizing is a second cause of the crisis of traditional justice. 
The Right to Have a Matter Adjudicated by a Court and Alternative Dispute...

in the law and in state institutions, and delivering a sense of stability and confidence. This trust in the courts should extend to the public generally, not just to those who appear before them. This leads directly to the actions aimed at humanizing civil procedure; the introduction of simple and effective solutions that are clear and easy to understand by people using the court's services. ${ }^{13}$ The effectiveness of legal protection can be studied through the prism of the barriers to court access, the existence and importance of alternative methods of resolving civil disputes and finally through the perception of the role of the courts in public opinion. ${ }^{14}$ Therefore in the process of humanization comparisons have to be drawn with the currently functioning model of traditional justice; where legal proceedings are conducted quite formally, technically and in a dehumanized manner in which the court is focused exclusively on the dispute while ignoring the human factors involved, to what extent can that be described as fair? ${ }^{15}$

The third cause of the crisis of traditional justice is the change in approach of the parties with respect to the perception of the proceedings as fair. Decisions based on procedural fairness may be seen as a failure to bring from the substantive (distributive) justice. Justice materially focuses primarily on just the separation of goods, on the outcome of the proceedings. Procedural justice is essentially focused on the process and on the way to achieving such purpose to resolve the issue. The greatest effect on the conduct of the parties is having the ability to fully express themselves known as voice effect - the effect of the voice. If the participants of the dispute are provided with the opportunity to fully and freely express themselves on their point of view, their fears, doubts and evidence, the process will be seen by them as more fair and honest, which gives rise to a high probability that the outcome of the case will be accepted, regardless of the trial itself. In addition, the participants are more likely to recognize the process as fair (fair trial) if they are treated with dignity and respect, impartially and in the same way as the opposing party. Parties to the proceedings appreciate more the opportunity to speak, giving them the respect and the dignity and equality of treatment. ${ }^{16}$ Within the framework of "righteous judgment" it must be emphasized that what is considered to be the right decision, is a decision which most closely corresponds with the law. One of the measures to achieve this goal is the complete and comprehensive statement of the judgment, especially when there are

13 K. Flaga-Gieruszyńska, Dostęp do sądu a postulat humanizacji procesu cywilnego, (in:) J. Gudowski, K. Weitz (eds.), Aurea Praxis Aurea Theoria. Księga pamiątkowa ku czci Profesora Tadeusza Erecińskiego, tom II, Warszawa 2011, pp. 2786-2787.

14 T. Ereciński, K. Weitz, Efektywność ochrony prawnej udzielanej przez sądy w Polsce, „Przegląd Sądowy" 2005, No. 10, p. 3.

15 A. Bieliński, Prawnik i jego misja..., op. cit., p. 30.

16 See E. Gmurzyńska, Sprawiedliwość a mediacja. Wybrane zagadnienia związane z realizowaniem koncepcji sprawiedliwości w mediacji, (in:) J. Gudowski, K. Weitz (eds.), Aurea Praxis Aurea Theoria..., op. cit., pp. 1680-1684. 
divergent interests of the parties and the decision must choose one over the other. In this case, the specific role of reasons of judgment is manifested in the belief that its position in the case was seriously considered and if another outcome failed, it was because the reasons were important. As established by law, the obligation to give reasons for such decisions lies in striving to respect the dignity and freedom of the citizen of a democratic state of law. ${ }^{17}$

Fourth in the causes of crisis within the classical justice system is that of the impact of time range in court decisions, which takes the direction of past to present. The court decides on facts that occurred in the past and reaches an outcome. The parties are often more interested in regulating relations in the future in such a way that in this area there would not have been conflicts, rather than receiving the separate outcome of the dispute. This is particularly important in these relations, while maintaining the appropriate relationship between the parties is essential - family relationships, between business partners, or labour issues. The possibility to establish the orientation of present to future arises in ADR, particularly in mediation, allowing the parties to present their expectations for the dispute. Court proceedings offer no such possibility, largely because the court is bound by the parties having specified the subject of the request for legal protection which does not extend to their personal expectations; here, following the rules of burden of proof is deemed the appropriate course of action and the basis on which decision is made.

The last of the contentious reasons to be mentioned relate exclusively to the traditional shortcomings of justice - costs, formalism and the excessive length of court procedures - and these require no amplification.

\section{The place of alternative dispute resolution in a justice system - conclusion}

Polish society is growing more and more aware of the limitations of traditional justice and conceptions of due process, and these traditional models are failing to meet public expectations in resolving disputes. Alternative methods of dispute resolution may perhaps be seen as the best way to resolve the problem of monocentric administration of justice, in which the courts have a monopoly on the settlement of disputes. Without doubt this monopoly requires to be broken, recognizing that the courts cannot and should not be the only or even the main institution to prevail over disputes in society. ${ }^{18}$ However, it should be noted that alternative dispute resolution (as a form of extra-judicial justice) cannot be included in the concept of justice because the Constitution entrusts the administration of justice only to the judiciary

17 E. Łętowska, Pozaprocesowe znaczenie uzasadnienia sądowego, „Państwo i Prawo” 1997, No. 5, p. 6.

18 See L. Morawski, Proces sądowy, a instytucje alternatywne..., op. cit., p. 18. 
The Right to Have a Matter Adjudicated by a Court and Alternative Dispute...

(art. 175 paragraph 1). Notwithstanding, the Constitution does not preclude the legality of the actions of non-state bodies being set up to resolve disputes, so long as the laws explicitly allow their creation, as for example in the case of mediation. ${ }^{19}$ Alternative dispute resolution is designed to complement the traditional justice system, especially in those areas where traditional lawsuits fail. These areas should be focused on smaller issues, low value of claim; cases in which there are no real legal issues merely misunderstanding and the like resulting in an inability to reach agreement; cases in which the conflicting parties are not really oriented in what they expect in front of the court. ${ }^{20}$ In such cases, even if a settlement before a mediator fails, the complementary role of mediation will have provided the parties with the opportunity to talk freely and openly about their respective view of the conflict and their expectations; leading to a better understanding of what the dispute is really about and being able to see, in a more convivial manner, the other side's point of view in relation to their own. Alternative dispute resolution is a good solution when the parties wish to maintain good future relations. The right to a court can be carried out either in the classical formula of a court of justice, or the use of alternative methods. It all depends on what the parties expect and on those expectations choosing the appropriate method for their cause. In the case of $\mathrm{ADR}$, emphasis is placed on the process of conflict resolution in a manner that is less formal and considerably more flexible than before a judge in a court of law. Indeed, it can be tempting to declare that only a system of legal protection so structured fully reflects the expectations of modern society, functioning in an environment subject to a number of dynamic changes of a different nature, conducive to the emergence of conflicts. It provides ordinary people with the opportunity to better understand their interests, thus protecting them in a more flexible way and opening the possibility of reaching a satisfactory solution to a dispute in a more rational and less formalized manner. ${ }^{21}$ Growing interest in the process and the use of ADR is also noticed by the judges themselves. I think they can now at least see the value of $\mathrm{ADR}$ in how it can assist a court when the dispute primarily relates to difficulties in communication rather than to any specific legal issue. ADR, particularly mediation, will also play a major role in multithreaded disputes, where analysis of all of the facts involved during trial is not possible. As mentioned earlier, relationships and the conditions under which we work have changed and still are changing. This also changes the very nature of conflicts, where traditional justice, at least in some cases, simply cannot cope. In such cases, a judgment invariably omits to take into account what

19 Patrz także $€$. Błaszczak, Alternatywne formy rozwiązywania sporów - analiza zjawiska na tle prawa polskiego, (in:) I. Ratusińska (ed.), Czterdziestolecie kodeksu postępowania cywilnego. Zjazd katedr postępowania cywilnego w Zakopanem (7-9 października 2005 r.), Kraków 2006, p. 335 .

20 As indicated earlier, this is crucial, due to the fact that the civil court is bound by the specified subject of the dispute and can't do generally more than a request to adjudicate.

21 A. Bieliński, Prawo do sądu..., op. cit. pp. 406-407. 
the parties themselves have identified as the interests they would like to see accomplished. Consequently, the court ruling completely fails to satisfy what the parties themselves call "fair ruling", i.e. implementing the principle of "procedural fairness." A verdict, based solely on the claims of the parties formally notified (perhaps not quite believing what they assert in court), can completely ignore the other threads that, as may later be accounted, underlay what the conflicting parties really expected to achieve. In the current realities of the functioning of the judiciary, quite often such court activity is not even possible because of time constraints. However, such cases open the door to the use of ADR, during which the parties, in an optimally controlled environment can reach agreement on the cause of the dispute between themselves, establish the spheres of interest they would like to accomplish and work out a satisfactory solution that is mutually acceptable. Statistics for the year 2016 and the beginning of 2017 seem to show a positive trend among both the courts and public interest in $\mathrm{ADR}$ procedures as a viable alternative to complement and, where possible, ease the administration of justice.

\section{BIBLIOGRAPHY}

Bieliński A., Prawnik i jego misja w ramach procedur alternatywnego rozwiązywania sporów w warunkach kryzysu klasycznego wymiaru sprawiedliwości, „Kwartalnik ADR” 2013, No. 2.

Bieliński A., Prawo do sądu a alternatywne metody rozwiązywania sporów ze szczególnym uwzględnieniem mediacji, (in:) Ł. Błaszczak (ed.), Konstytucjonalizacja postępowania cywilnego, Wrocław 2015.

Błaszczak Ł., Alternatywne formy rozwiązywania sporów - analiza zjawiska na tle prawa polskiego, (in:) I. Ratusińska (ed.), Czterdziestolecie kodeksu postępowania cywilnego. Zjazd katedr postępowania cywilnego w Zakopanem (7-9 października 2005 r.), Kraków 2006.

Ereciński T., Weitz K., Efektywność ochrony prawnej udzielanej przez sądy w Polsce, „Przegląd Sądowy” 2005, No. 10.

Flaga-Gieruszyńska K., Dostęp do sądu a postulat humanizacji procesu cywilnego, (in:) J. Gudowski, K. Weitz (eds.), Aurea Praxis Aurea Theoria. Księga pamiątkowa ku czci Profesora Tadeusza Erecińskiego, tom II, Warszawa 2011.

Gmurzyńska E., Sprawiedliwość a mediacja. Wybrane zagadnienia związane z realizowaniem koncepcji sprawiedliwości w mediacji, (in:) J. Gudowski, K. Weitz (eds.), Aurea Praxis Aurea Theoria. Księga pamiątkowa ku czci Profesora Tadeusza Erecińskiego, tom II, Warszawa 2011.

Jasińska J., Prawo do sądu na tle polskiego prawa cywilnego materialnego i procesowego, (in:) R. Sztychmiler, J. Krzywkowska, Problemy z sądową ochroną praw człowieka, tom I, Olsztyn 2012.

Łętowska E., Pozaprocesowe znaczenie uzasadnienia sądowego, „Państwo i Prawo” 1997, No. 5.

Mądrzak H., Prawo do sądu jako gwarancja ochrony praw człowieka (studium na tle polskiego prawa konstytucyjnego, prawa cywilnego materialnego i procesowego), (in:) L. Wiśniewski (ed.), Podstawowe prawa jednostki i ich sądowa ochrona, Warszawa 1997. 
The Right to Have a Matter Adjudicated by a Court and Alternative Dispute...

Morawski L., Proces sądowy, a instytucje alternatywne (na przykładzie sporów cywilnych), „Państwo i Prawo" 1993, No. 1.

Pogonowski P., Realizacja prawa do sądu w postępowaniu cywilnym, Warszawa 2005.

Resich Z., Istota procesu cywilnego, Warszawa 1985.

Resich Z., Przesłanki procesowe, Warszawa 1966.

Szczechowicz J., Ochrona praw człowieka w aspekcie prawa dostępu do sądu w postępowaniu cywilnym, (in:) R. Sztychmiler, J. Krzywkowska, Problemy z sądową ochroną praw człowieka, tom I, Olsztyn 2012. 
